\title{
Pelatihan "Action" untuk Meningkatkan Keterampilan Stimulasi Literasi pada Guru TK
}

\author{
Zahra Santika Utari ${ }^{1} \mathcal{E}$ Wisjnu Martani ${ }^{2}$ \\ Fakultas Psikologi Universitas Gadjah Mada
}

\begin{abstract}
This study aimed at examining the influence of "ACTION" training on improvement of kindergarten teachers' skills of literacy stimulation. "ACTION" training was a training provided for teachers as scaffolder by using activities of sociodrama to improve literacy stimulation skills. The design employed in this study was untreated group control design with dependent pretest and posttest samples. The subjects were 18 kindergarten teachers (9 teachers in experimental group and 9 teachers in control group). The research instruments used were "ACTION" training module, observation guide for literacy stimulation skills, knowledge test of literacy stimulation, and knowledge test sociodrama activity. The statistical test used was Mann-Whitney U Test. The results of the study showed that stimulation literacy skills were significantly higher in experimental group than in control group $(U=0.000 ; p<$ 0.05). This study concluded that "ACTION" training could improve kindergarten teachers' skills of literacy stimulation.
\end{abstract}

Keywords: kindergarten teacher; literacy stimulation; sociodramatic play

Abstrak. Penelitian ini bertujuan menguji pengaruh pelatihan "ACTION" pada peningkatan keterampilan stimulasi literasi pada guru taman kanak-kanak (TK). Pelatihan "ACTION" merupakan pelatihan guru sebagai scaffolder menggunakan aktivitas bermain sosiodrama untuk meningkatkan keterampilan stimulasi literasi. Desain penelitian yang digunakan adalah untreated control group design with dependent pretest and postest samples. Subjek penelitian berjumlah 18 guru TK (9 guru pada kelompok eksperimen dan 9 guru pada kelompok kontrol). Instrumen penelitian yang digunakan antara lain modul pelatihan "ACTION", panduan observasi keterampilan stimulasi literasi, tes pengetahuan stimulasi literasi, dan tes pengetahuan aktivitas bermain sosiodrama. Uji statistik menggunakan Mann-Whitney U Test. Hasil penelitian menunjukkan keterampilan stimulasi literasi secara signifikan lebih tinggi pada kelompok eksperimen dibandingkan kelompok kontrol $(U=0,000 ; p<0,05)$. Penelitian ini menyimpulkan bahwa pelatihan "ACTION" dapat meningkatkan keterampilan stimulasi literasi pada guru TK.

Kata kunci: guru TK; stimulasi literasi; bermain sosiodrama

\footnotetext{
${ }^{1}$ Korespondensi dapat dilakukan melalui:zahra.santika.u@gmail.com

${ }^{2}$ Atau melalui wisjnu m@ugm.ac.id
} 

Literasi diartikan sebagai kemampuan individu dalam menggunakan bahasa lisan, membaca, menulis, dan mendengar untuk berkomunikasi dan berinteraksi dengan lingkungan (Morrow, 2007). Literasi tidak lepas dari bahasa, seseorang dikatakan memiliki keterampilan literasi apabila ia telah memperoleh kemampuan dasar berbahasa.

Vygotsky (1978) mengatakan bahwa anak belajar bahasa dipengaruhi oleh konteks sosial dan budaya. Konteks sosial yang dimaksud adalah interaksi sosial anak dengan orang yang lebih ahli, sedangkan budaya merupakan alat yang membantu mengkonstruksi kemampuan anak mencakup aktivitas pembelajar atau media yang dapat digunakan oleh anak. Adanya interaksi sosial antara guru dan anak membantu anak untuk menginternalisasikan suatu konsep dan keterampilan. Alat mediasi yang dapat digunakan antara lain suatu hal yang konkrit dan dapat digunakan anak, seperti halnya media bermain.

Fenomena saat ini, banyak anak usia dini yang mengikuti program pendidikan Taman Kanak-Kanak (TK). Interaksi sosial antara guru dan anak menjadi salah satu faktor dalam perkembangan literasi anak dalam program pendidikan TK (Copple \& Bredekamp, 2009). Guru merupakan faktor konteks sosial yang penting untuk membantu anak menguasai keterampilan literasi (Whitehead, 2007). Guru perlu memiliki keterampilan stimulasi literasi dengan tepat, yang artinya stimulasi yang diberikan oleh guru harus sesuai dengan kebutuhan anak sehingga menciptakan kemampuan optimal (Baneerje, Alsalman, \& Alqafari, 2016; Copple \& Bradekamp, 2009; Bodrova \& Leong, 2007; TrawickSmit \& Dziurgot, 2011). Vygotsky (1978) menekankan pentingnya menciptakan Zone of Proximal Development (ZPD), karena anak belajar konsep paling baik apabila konsep tersebut berada pada zona perkembangan terdekat mereka. ZPD diartikan sebagai zona antara zona perkembangan aktual dan perkembangan potensial.

Keterampilan stimulasi literasi merupakan strategi atau teknik yang digunakan guru dalam meningkatkan kualitas dan kuantitas interaksi antara guru dan anak untuk membantu anak mengembangkan keterampilan literasi. Stimulasi literasi yang diberikan oleh guru menggunakan interaksi verbal yang bertujuan untuk meningkatkan kemampuan anak dalam mengenal konsep bahasa sebagai kemampuan dasar keterampilan literasi (Turnbull, Anthony, Justice, \& Bowles, 2009; Justice, Mashburn, Pence, \& Wiggins, 2008).

Keterampilan stimulasi literasi mencakup 1) memberikan pernyataan ataupun komentar yang mencakup suara, kata benda, atau struktur bahasa yang belum dikuasai anak (model), 2) memberikan deskripsi terkait dengan kejadian atau aktivitas yang sedang berlangsung (event cast), 3) mengajukan pertanyaan dengan kemungkinan jawaban yang bervariasi (open question), 4) memberikan komentar dengan menambahkan informasi dari perkataan yang diucapkan anak (recast/expansion), 5) meminta anak untuk melakukan interaksi /percakapan dengan teman sebaya (redirect/prompt), dan 6) memberikan penjelasan terkait perbedaan antara dua suara huruf atau struktur bahasa (focused contrast) (Rice \& Wilcox, dalam Turnbull, et al., 2009).

Berdasarkan data Programme for International Student Assesment (PISA) tahun 2015 kemampuan membaca di Indonesia berada pada kategori di bawah rata-rata. Selain itu, berdasarkan hasil penelitian PISA tahun 2015, kemampuan 
membaca di Indonesia belum ada peningkatan dari penelitian yang telah dilakukan tahun 2012. Di sisi lain, kompetensi sains dan matematika mengalami peningkatan dibandingkan tahun 2012. Pada tahun 2011, Progress in International Reading Literacy Study (PIRLS) melakukan asesmen terkait dengan keterampilan literasi kepada siswa kelas empat di Indonesia, diketahui bahwa keterampilan literasi anak Indonesia termasuk kategori intermediatelow. Berdasarkan hasil penelitian dari PISA maupun PIRLS, dapat ditarik kesimpulan bahwa keterampilan literasi anak di Indonesia masih berada pada kategori rendah. Temuan penelitian ini menegaskan pentingnya stimulasi literasi oleh guru sebagai upaya membantu mengembangkan keterampilan literasi anak dan sebagai preventif terkait dengan permasalahan anak dalam membaca (Goldstein, 2011). Dari studi pendahuluan yang dilakukan di empat TK di Yogyakarta, diketahui sebagian besar guru kurang memberikan verbal feedback kepada anak dan cenderung mengajukan pertanyaan tertutup sehingga hal ini menyebabkan anak memiliki kesempatan yang minim dalam mengembangkan kemampuan bahasa (Copple \& Bradekamp, 2009).

Menurut Copple dan Bredekamp (2009), di dalam memberikan pengajaran pada anak hendaknya guru mampu untuk mengajukan pertanyaan dan membangun dialog atau diskusi dengan anak. Guru juga perlu mengajukan pertanyaan yang memberikan kesempatan lebih banyak pada anak untuk mengekspresikan pikiran dan penggunaan bahasa. Hal ini bertujuan untuk mendorong anak mengembangkan kemampuan bahasa.

Dalam perspektif sosiokultural, stimulasi yang diberikan oleh guru merupakan bentuk scaffolding, yaitu bantuan atau bimbingan yang diberikan oleh orang yang lebih ahli dengan tujuan membantu anak agar mampu menyelesaikan tugas atau mampu mencapai tujuan tertentu di luar kemampuan aktualnya (van de Pol, et. al., 2010; Morrow, 2007; Brownee, 2001).

Saat memberikan stimulasi literasi dibutuhkan alat mediasi yakni konteks aktivitas yang merupakan ragam aktivitas yang digunakan sebagai media pembelajaran (Pence \& Wiggins, 2008). Berdasarkan wawancara pada studi pendahuluan, salah satu media stimulasi literasi yang digunakan guru adalah aktivitas bermain sosiodrama. Turnbull, et al. (2009) mengatakan bahwa konteks aktivitas yang digunakan memengaruhi guru dalam mengembangkan keterampilan stimulasi literasi. Aktivitas bermain sosiodrama merupakan konteks aktivitas yang memberikan banyak kesempatan pada guru memberikan stimulasi literasi (Turnbull, et.al, 2009; Pence \& Wiggins, 2008).

Berdasarkan wawancara guru dalam studi pendahuluan, kendala yang ditemukan bermain sosiodrama adalah kurangnya sumber daya dalam membuat material pendukung. Media paper and pencil yang digunakan kurang memberikan kesempatan untuk guru memberikan stimulasi dalam bahasa lisan karena minimnya verbal feedback yang diberikan (Copple \& Bredekamp, 2009).

Peneliti melakukan observasi terhadap dua guru dalam menggunakan aktivitas bermain sosiodrama pada saat studi pendahuluan. Guru belum tepat dalam memberikan stimulasi literasi dengan menggunakan media tersebut. Hal ini ditunjukkan bahwa guru kehilangan momen untuk mengajukan pertanyaan terbuka dan tidak memberikan verbal feedback pada anak. Guru gagal dalam menciptakan peran 
yang sesuai dengan pengetahuan anak yang telah dibentuk sebelumnya. Selain itu guru masih kesulitan untuk menentukan alur cerita yang dapat digunakan dan merasa sulit dalam melibatkan anak untuk mampu menggunakan bahasa lisan dan perbendaharaan kata. Kurang tepatnya stimulasi literasi yang diberikan oleh guru disebabkan stimulasi yang diberikan tidak mengikuti prinsip ZPD dan aktivitas pembelajaran yang digunakan kurang memberikan kesempatan untuk mengembangkan keterampilan stimulasi literasi.

Berdasarkan asesmen kebutuhan di lapangan, program yang dibutuhkan adalah pelatihan untuk meningkatkan keterampilan stimulasi guru TK. Peneliti menyusun pelatihan untuk menanggapi kebutuhan-kebutuhan yang telah diidentifikasi. Pelatihan terkait dengan teknik stimulasi literasi untuk diberikan kepada guru, karena tanpa mengetahui teknik yang tepat maka program pembelajaran yang dilaksanakan kurang optimal dalam mengembangkan keterampilan literasi anak (Wasik, 2010). Penelitian menyusun program pelatihan yang diberi nama pelatihan "ACTION" (Active, Creative, Thematic, Initiative, Optimum, dan $f u N$ ), yakni pelatihan yang diberikan untuk guru TK sebagai scaffolder dengan aktivitas bermain sosiodrama.

Di dalam pelatihan, guru akan mendapat scaffolding berupa feedback dari orang lain, sharing pengalaman (Engin, 2014), dan berlatih menggunakan media yang spesifik untuk stimulasi literasi. Pelatihan "ACTION" disusun berdasarkan aspek bermain sosiodrama yang perlu diperhatikan guru sebagai scaffolder diungkapkan oleh El'konin (dalam Gmitrova, 2013) antara lain, manipulasi benda (things) yakni guru mempersiapkan material atau mainan yang akan digunakan untuk bermain sosiodrama, membentuk peran (roles), dan adanya komunikasi verbal (words). Pelatihan yang dilakukan menggunakan pendekatan Zone of Proximal Teacher Development (ZPTD) dan metode yang digunakan adalah diskusi, microteaching, role play, pengerjaan lembar kerja, dan diskusi kasus (Warford, 2011).

Penelitian ini bertujuan untuk menguji pengaruh pelatihan "ACTION" pada peningkatan keterampilan stimulasi literasi pada guru TK. Hipotesis dalam penelitian ini adalah terdapat perbedaan peningkatan keterampilan stimulasi literasi kelompok eksperimen dibandingkan kelompok kontrol.

\section{Metode}

\section{Identifikasi variabel}

Varibel tergantung dalam penelitian ini adalah keterampilan stimulasi literasi yang secara operasional didefinisikan sebagai teknik atau strategi yang digunakan dalam meningkatkan kualitas dan kuantitas interaksi antara guru dan anak sebagai upaya membantu anak mengembangkan keterampilan literasi tertentu. Sedangkan, variabel bebas dalam penelitan adalah pelatihan "ACTION" yang disusun untuk meningkatkan keterampilan stimulasi literasi dengan media aktivitas bermain sosiodrama.

\section{Subjek penelitian}

Subjek dalam penelitian adalah guru YK di wilayah Unit Pelaksana Teknis (UPT) Utara kota Yogyakarta. Kriteria subjek penelitian dalam penelitian adalah 1) berlatar belakang pendidikan minimal S1 dan sebagai guru wali kelas, 2) sudah bekerja sebagai guru minimal dalam jangka waktu dua tahun, 3) belum pernah mengikuti pelatihan tentang stimulasi 
literasi, 4) skor tes pengetahuan stimulasi literasi dan tes pengetahuan aktivitas bermain sosiodrama berada pada kategori sedang, dan 5) bersedia berpartisipasi menjadi subjek dalam penelitian ini dari awal hingga akhir.

Screening subjek dilakukan terhadap 56 guru TK dan didapatkan 26 subjek yang sesuai dengan kriteria penelitian. Dari 26 subjek yang menyatakan kesediaannya untuk terlibat dalam penelitian ini adalah sebanyak 20 subjek. Pembentukan kedua kelompok dilakukan dengan menanyakan kesediaan masingmasing TK untuk mengikuti pelatihan "ACTION". Apabila subjek bersedia untuk mengikuti pelatihan "ACTION" maka akan dilibatkan sebagai subjek kelompok eksperimen, sementara kelompok kontrol adalah guru yang tidak dapat mengikuti pelatihan "ACTION", namun bersedia terlibat mengikuti pretest dan posttest. Terdapat sepuluh subjek dalam kelompok eksperimen maupun dalam kelompok kontrol. Namun terjadi mortalitas pada kelompok eksperimen maupun kelompok kontrol sehingga jumlah subjek pada kelompok ekperimen sebanyak sembilan subjek dan kelompok kontrol sebanyak sembilan subjek.

\section{Instrumen penelitian}

Pertama menggunakan tes pengetahuan stimulasi literasi. Tes pengetahuan stimulasi literasi disusun berdasarkan penjelasan Turnbull, et. al. (2008), Morrow (2007), Bodrova dan Leong (2007) yakni terdiri dari 1) perkembangan literasi anak usia dini, 2) prinsip ZPD, dan 3) media stimulasi literasi. Tes tersebut digunakan sebagai screening subjek dan merupakan jenis tes pilihan ganda yang terdiri dua belas aitem. Estimasi koefisien reliabilitas sebesar 0,728. Kedua menggunakan tes pengetahuan aktivitas bermain sosiodrama. Tes tersebut disusun berdasarkan komponen dari bermain sosiodrama yang diungkapkan El'konin (dalam Gmitrova, 2013), yaitu 1) manipulasi benda (things), 2) membentuk peran (roles), dan 3) komunikasi verbal (words). Tes pengetahuan aktivitas bermain sosiodrama digunakan sebagai screening subjek penelitian dan cek manipulasi. Tes ini merupakan jenis tes pilihan ganda yang terdiri dari 14 aitem dengan estimasi koefisien reliabilitas sebesar 0,747 .

Instrumen lain yang digunakan adalah panduan observasi keterampilan stimulasi literasi. Panduan observasi yang digunakan berdasarkan panduan observasi yang disusun oleh Turnbull, et.al (2008). Metode observasi yang digunakan adalah event sampling (pada konteks aktivitas bermain sosiodrama). Estimasi koefisien interrater reliability dianalisis dengan interclass correlation (ICC) menghasilkan rata-rata kesepakatan antar rater pada indeks 0,925. Selanjutnya menggunakan Modul "ACTION". Modul disusun oleh peneliti berdasarkan aspek aktivitas bermain sosiodrama yang perlu diperhatikan guru sebagai scaffolder yang diungkapkan oleh El'konin (dalam Gmitrova, 2013). Skor Aiken's V sebesar 0,76 hingga 0,87 .

\section{Prosedur penelitian}

Penelitian menggunakan desain eksperimen untreated control group design with dependent pretest and posttest samples (Shadish, Cook, \& Campbell, 2002). Penelitian ini mengukur keterampilan stimulasi literasi sebanyak dua kali, yakni sebelum diberikan manipulasi (pretest) dan setelah diberikan manipulasi (posttest). Pengukuran dilakukan dengan metode observasi event sampling, yaitu pada saat aktivitas bermain sosiodrama dilakukan. Manipulasi eksperimen adalah pem-berian pelatihan "ACTION" pada kelompok eksperimen. 
Tabel 1.

Sesi Pelatihan "ACTION"

Sesi

Tujuan

Memfasilitasi peserta untuk memahami perkembangan literasi anak usia dini dan media stimulasi literasi yang dapat digunakan untuk stimulasi literasi
Diskusi kelompok, anak usia dini

(Hari ke-1)

Memfasilitasi peserta untuk memahami

Sesi 2: Pentingnya stimulasi literasi scaffolding secara tepat untuk mengembangkan keterampilan literasi anak secara optimal (ZPD)

pengerjaan lembar

Diskusi kelompok, studi kasus

(Hari ke-1) pentingnya memberikan stimulasi literasi yakni dengan memberikan

Metode

Sesi 3: Siap untuk mempersiapkan media bermain sambil belajar

(Hari ke-2)

Membantu peserta untuk
mengembangkan kemampuan melakukan persiapan dalam bermain sosiodrama meliputi pemilihan tema, menyiapkan tempat untuk bermain

Diskusi kelompok, pengerjaan lembar kerja sosiodrama, dan menyiapkan peran bagi anak

Sesi 4: Mari bermain sosiodrama

(Hari ke-2)

Membantu peserta untuk

mengembangkan kemampuan untuk menentukan peran dalam bermain sosiodrama dan membangun

Diskusi kelompok, microteachng pengetahuan anak terkait dengan peran tersebut

Sesi 5: Pentingnya

komunikasi verbal dalam bermain sosiodrama

Membantu peserta untuk

Diskusi kelompok, role mengembangkan kemampuan play, studi kasus, memberikan scaffolding secara verbal pengerjaan lembar kerja

(Hari ke-3)

Sesi pelatihan "ACTION" dapat dilihat pada tabel 1. Pelatihan "ACTION" terdiri dari lima sesi yang dibawakan dengan pendekatan pembelajaran ZPTD.

Pelatihan "ACTION" dilakukan sebanyak tiga kali pertemuan dengan durasi 2,5 jam/pertemuan. Pelatihan "ACTION" dibawakan oleh fasilitator dengan kualifikasi psikolog, memiliki pengalaman berinteraksi dengan guru TK minimal dua tahun, dan memiliki pengalaman menjadi fasilitator (trainer) memberikan materi di hadapan guru, dan memiliki pengetahuan tentang perkembangan literasi anak usia dini. Kofasilitator pada pelatihan ini berperan sebagai pemandu dalam diskusi kelompok kecil, kualifikasinya adalah memiliki latar belakang ilmu psikologi, berpengalaman sebagai fasilitator maupun kofasilitator dalam memandu pelatihan, dan memiliki pengetahuan tentang perkembangan literasi anak usia dini. 


\section{Analisis data}

Data penelitian ini akan dianalisis dengan menggunakan uji statistika nonparametrik. Uji Mann-Whitney U Test digunakan untuk melihat perbedaan skor antara dua kondisi subjek yang independen (Howitt \& Cramer, 2011). Didalam penelitian ini, skor yang dibandingkan adalah gain score keterampilan stimulasi literasi antara kelompok eksperimen dan kelompok kontrol.

\section{Hasil}

\section{Uji hipotesis}

Uji statistik menggunakan Mann-Whitney

$U$ Test menunjukkan terdapat perbedaan peningkatan keterampilan stimulasi literasi yang signifikan antara kelompok ekperimen dibandingkan kelompok kontrol $(U=0,000, p<0,05)$. Kelompok ekperimen menunjukkan mean rank 14, sedangkan kelompok kontrol menunjukkan mean rank 5. Dengan demikian, hipotesis dalam penelitian ini diterima.

Peneliti juga melakukan analisis terhadap perbedaan peningkatan pengetahuan stimulasi literasi pada kelompok eksperimen dan kelompok kontrol menggunakan Mann-Whitney $U$ Test. Berdasarkan hasil analisis tersebut, diketahui bahwa terdapat perbedaan peningkatan pengetahuan stimulasi literasi yang signifikan antara kelompok ekperimen dan kelompok kontrol $(U=$ 6,500; $p<0,05)$. Kelompok ekperimen memiliki mean rank 13,28, sedangkan kelompok kontrol memiliki mean rank 5,72. Menurut Fritz, Morris, dan Richler (2012) effect size untuk uji statistik nonparametrik dapat diketahui dengan membagi $\mathrm{Z}$ dengan akar $\mathrm{N}$, sehingga effect size (sumbangan efektif) pelatihan "ACTION" terhadap peningkatan keterampilan stimulasi literasi pada guru TK sebesar $84 \%$.

\section{Analisis kualitatif}

Analisis kualitatif dalam penelitian ini dilakukan untuk mendukung data kuantitatif yang sudah ada. Berdasarkan analisis Mann-Whitney $U$ Test, terdapat perbedaan peningkatan keterampilan stimulasi literasi pada kelompok eksperimen dibandingkan kelompok kontrol. Hal tersebut terlihat pula pada observasi yang dilakukan pada saat pretest dan posttest pada keterampilan stimulasi literasi. Pada saat pretest maupun posttest, subjek diminta untuk melakukan aktivitas bermain sosiodrama bersama dengan siswa di kelasnya dan keterampilan stimulasi literasi subjek diamati.

Pada saat pretest, sebagian besar subjek pada kelompok eksperimen maupun kelompok kontrol kurang memberikan verbal feedback dan pertanyaan yang diajukan kurang memberikan kesempatan pada anak untuk menggunakan bahasa lisan lebih banyak. Pada aktivitas bermain sosiodrama, subjek tidak membantu anak untuk memahami peran dan alur cerita dengan benda yang konkret sehingga stimulasi literasi yang diberikan minim. Saat anak bermain sosiodrama, beberapa subjek cenderung tidak mendampingi anak untuk bermain sosiodrama, namun melakukan aktivitas lain sehingga kurangnya stimulasi literasi yang diberikan.

Setelah pelatihan "ACTION" diberikan, satu minggu kemudian keterampilan stimulasi literasi subjek diukur kembali pada saat aktivitas bermain sosiodrama (posttest). Aktivitas bermain sosiodrama yang dilaksanakan subjek dilakukan mengikuti ketiga aspek dari pelatihan yang telah diberikan yaitu adanya things, words, dan roles (El'Konin dalam Gmitrova, 2013). Berdasarkan hasil pengukuran posttest, subjek pada kelompok eksperimen menunjukkan 
perubahan dalam stimulasi literasi mencakup keenam aspek keterampilan stimulasi literasi Rice dan Wilcox (dalam Turnbul, et. al., 2009). Disisi lain, subjek pada kelompok kontrol tidak menunjukkan perubahan dalam stimulasi literasi.

\section{Hasil observasi}

Dari hasil penilaian yang diberikan ketiga observer menunjukkan bahwa ketercapaian aktivitas pelatihan yang dilakukan sebesar $87 \%$. Berdasarkan hasil observasi selama pelatihan berlangsung, diketahui keaktifan masing-masing peserta pada aktivitas diskusi, praktik, mendengarkan dan memperhatikan instruksi, dan melaksanakan tugas tiap sesi. Berdasarkan hasil observasi yang dilakukan, seluruh peserta pelatihan mengikuti setiap aktivitas dalam sesi pelatihan dengan aktif dan antusias.

\section{Cek manipulasi}

Tes pengetahuan aktivitas bermain sosiodrama digunakan sebagai cek manipulasi, yaitu untuk mengetahui apakah pelatihan yang diberikan sudah sesuai dengan materi yang dimaksud oleh peneliti (Sugiyanto, 2009).

Berdasarkan uji Wilcoxon Signed Ranks Test terhadap pengetahuan aktivitas bermain sosiodrama pada kelompok eskperimen menunjukkan nilai $Z=-2,684(p<0,05)$, yang artinya terdapat perbedaan yang signifikan pengetahuan aktivitas bermain sosiodrama sebelum dan setelah manipulasi eksperimen diberikan. Lebih lanjut dilakukan analisis yang sama pada kelompok kontrol dan didapatkan nilai $Z=-1,265(p>0,05)$, menunjukkan tidak ada perbedaan pengetahuan aktivitas bermain sosiodrama sebelum dan sesudah manipulasi eksperimen pada kelompok kontrol.

\section{Diskusi}

Penelitian ini bertujuan untuk menguji pengaruh pemberian pelatihan Action terhadap peningkatan keterampilan stimulasi literasi pada guru TK. Hasil analisis menggunakan Mann-Whitney $U$ Test menunjukkan bahwa terdapat perbedaan peningkatan keterampilan stimulasi literasi yang signifikan antara kelompok eksperimen dibandingkan kelompok kontrol $(U=0,000 ; p<0,05)$. Dengan demikian, pelatihan "ACTION" terbukti dapat meningkatkan keterampilan stimulasi literasi. Pembahasan dalam penelitian ini membahas dua hal utama keberhasilan peningkatan keterampilan stimulasi literasi pada guru TK, yakni diberikannya pelatihan "ACTION" dan alur penyampaian pelatihan sosiokultural yang digunakan dalam pelatihan.

Pelatihan "ACTION" merupakan pelatihan guru sebagai scaffolder dalam aktivitas bermain sosiodrama sebagai media stimulasi literasi dan disusun berdasarkan aspek things, roles, dan words yang diungkapkan oleh El'Konin (dalam Gmitrova, 2013). Selain itu dalam pelatihan, adanya pemberian informasi terkait literasi, tahapan perkembangan literasi, dan media stimulasi dalam manipulasi eksperimen merupakan dasar pengetahuan guru untuk terampil memberikan stimulasi literasi (Saracho, 2004). Schachter, Spear, Piasta, Justice, dan Logan (2016) mengungkapkan bahwa pengetahuan guru yang tinggi tidak memprediksi akan berpengaruh terhadap keterampilan yang tinggi pula, meskipun begitu pengetahuan stimulasi literasi dapat menunjang praktik stimulasi literasi. Pemberian informasi yang tedapat pada pelatihan "ACTION" meningkatkan pengetahuan stimulasi literasi, terbukti dari hasil analisis MannWhitney $U$ Test bahwa terdapat perbedaan 
pe-ningkatan pengetahuan stimulasi literasi pada kelompok eksperimen dibandingkan kelompok kontrol $(U=$ 6,500; $p<0,05$ ).

Pada aspek pelatihan "ACTION" manipulasi benda (things), subjek diberikan informasi terkait persiapan yang perlu dilakukan untuk mengoptimalkan aktivitas bermain sosiodrama sebagai media stimulasi literasi (Gmitrova, 2013). Lingkungan fisik yang mendukung dalam memberikan stimulasi literasi meliputi ketersediaan material literasi yang mudah diakses oleh anak. Persiapan yang dilakukan oleh guru terkait dengan lingkungan yang "kaya" literasi mendukung keterampilan stimulasi literasi guru (Roskos \& Chritie, 2013).

Pada aspek pelatihan membentuk peran (roles), subjek dilatih untuk membentuk peran untuk anak yaitu dengan cara membacakan buku cerita. Pada aspek ini, subjek memberikan scaffolding mengajukan pertanyaan, modelling, dan umpan balik saat membacakan buku cerita. Hal ini sesuai dengan penelitian Roskos dan Christie (2011) bahwa membacakan buku cerita untuk membangun pengetahuan anak terkait peran dan alur cerita memberikan kesempatan untuk guru memberikan stimulasi literasi pada anak dengan mengenalkan perbendaharaan kata baru dan meminta anak mengulangnya (say), menjelaskan kata atau kalimat yang belum diketahui anak (tell) dan meminta anak untuk bermain sosiodrama dari cerita yang telah didiskusikan (do).

Pada aspek komunikasi verbal (words), subjek juga memberikan scaffolding mengajukan pertanyaan, modelling, dan umpan balik pada saat mendampingi anak bermain sosiodrama. Scaffolding yang diberikan oleh guru saat anak bermain sosiodrama harus disesuaikan dengan kebutuhan anak (Trawick-Smith \& Dziourgot, 2011), sehingga guru mendapatkan kesempatan untuk mengembangkan keterampilan stimulasi mengajukan pertanyaan kepada anak, memberikan komentar dari perkataan yang dilontarkan anak yang dapat memberikan informasi pada anak, meminta anak untuk melakukan interaksi/percakapan dengan teman sebaya, dan menjelaskan terkait perbedaan suara huruf.

$$
\text { Gmitrova (2013) mengatakan }
$$

bahwa aktivitas bermain sosiodrama, memberikan kesempatan pada guru untuk lebih banyak membangun komunikasi kepada anak, seperti mengajukan pertanyaan terbuka dan modelling verbal, hal ini sebagai bentuk scaffolding yang diberikan guru pada anak. Berdasarkan penelitian Turnbull, et. al (2009) diketahui bahwa aktivitas bermain sosiodrama merupakan aktivitas berpusat pada anak dan memberikan kesempatan paling banyak untuk guru melakukan interaksi verbal meliputi memberikan umpan balik terkait perkataan yang diucapkan oleh anak, memberikan penjelasan terkait suatu kata atau kalimat, dan terlibat dalam percakapan. Aktvitas bermain sosiodrama lebih banyak memberikan kesempatan bagi guru untuk memberikan stimulasi literasi dibandingkan dengan aktivitas membaca buku cerita (Pence \& Wiggins, 2008).

Keberhasilan pelatihan "ACTION" juga dapat dilihat dari pemahaman aktivitas bermain sosiodrama pada peningkatan kelompok eksperimen. Peningkatan pengetahuan stimulasi literasi pada subjek kelompok eksperimen setelah diberikan pelatihan "ACTION" dibuktikan melalui pengukuran aktivitas bermain sosiodrama menggunakan uji Wilcoxon Sign Ranks Test dengan nilai $Z=$ 
$-2,684 \quad(p<0,05)$. Sedangkan pada kelompok kontrol pengetahuan aktivitas bermain sosiodrama pada kelompok kontrol didapatkan nilai $Z=-1,265$ ( $p>$ $0,05)$. Hal ini menunjukkan bahwa tidak ada perbedaan pengetahuan aktivitas bermain sosiodrama pada kelompok kontrol. Hasil ini membuktikan bahwa subjek pada kelompok eksperimen memahami materi pelatihan "ACTION" yang diberikan dan manipulasi eksperimen yang diberikan sudah sesuai dengan apa yang dirancang (Sugiyanto, 2009).

Tiap sesi pelatihan mengikuti keempat tahapan sosiokultural, yaitu self assistance, fasilitator memberikan kesempatan pada peserta untuk sharing atau berbagi pengalaman dan pengetahuan yang dimiliki. Pengalaman dan pengetahuan yang dimiliki oleh peserta menjadikan dasar fasilitator dan kofasiliator dalam memberikan scaffolding dalam pelatihan, seperti mengajukan pertanyaan, modelling dan umpan balik (Wardford, 2011).

Pada tahapan kedua adalah expert other assistance dilakukan dengan menyajikan kasus untuk dianalisis oleh peserta secara berkelompok, menyaksikan video, dan mendengarkan pemaparan materi oleh fasilitator. Pada tahapan ini, peserta dapat melakukan eksplorasi dan fasilitator beserta kofasilitator memberikan scaffolding sesuai dengan kebutuhan.

Pada tahapan internalization, peserta diajak untuk mengerjakan lembar kerja dan praktik, sehingga peserta dapat menginternalisasikan pengalaman barunya (Shabani, Khatib, \& Ebadi, 2010; Warford, 2011, Fani \& Ghaemi; 2011). Pada tahapan ini, proses internalisasi pengalaman baru ditandai dengan peserta mampu untuk melakukan tugas yang diberikan dalam setiap sesi pelatihan meskipun dengan bimbingan dari fasilitator dan kofasilitator karena dengan adanya bimbingan, maka nantinya peserta akan mampu melaksanakan tugas tersebut dengan mandiri. Pada tahapan terakhir yakni reccurance, peserta melakukan evaluasi terhadap pembelajaran yang telah dilakukannya meliputi perencanaan dan hambatan yang dihadapi (Warford, 2011). Pada tahapan ini, fasilitator membantu peserta untuk membuat kesimpulan dari pengalaman pembelajaran yang telah dilakukan. Fasilitator dan ko-fasilitator memberikan scaffolding pada zona proksimalnya yakni guru mampu menguasai suatu keterampilan dengan adanya bimbingan dari fasilitator dan kofasilitator hingga akhirnya guru dapat mempraktikkan keterampilan tersebut secara mandiri.

Pemaparan di atas menunjukkan bahwa pelatihan "ACTION" dapat meningkatkan keterampilan stimulasi literasi pada guru TK. Namun, penelitian ini tidak lepas dari keterbatasan. Penelitian tidak melakukan randomisasi pada proses alokasi kelompok eskperimen dan kelompok kontrol. Alokasi kelompok eksperimen dan kontrol hanya berdasarkan pada kesediaan guru untuk melakukan pelatihan "ACTION". Hal ini berdampak pada validitas internal selection, yaitu adanya efek yang diakibatkan karena perbedaan jenis subjek antara kedua kelompok. Kelompok kontrol akan mendapatkan perlakuan yang berbeda dan bukan kelompok yang secara probabilistik setara seperti halnya dalam rancangan eksperimen random (Shadish, et. al., 2002). Keterbatasan lainnya adalah pada pelatihan yang dilakukan tidak ada sesi praktik sebagai scaffolder dalam aktivitas bermain sosiodrama pada setting sesungguhnya sehingga tidak adanya 
pengamatan implementasi pelatihan dalam berpraktik sebagai scaffolder aktivitas bermain sosiodrama sesuai dengan pelatihan yang diberikan.

\section{Kesimpulan}

Hasil penelitian menunjukkan bahwa pelatihan "ACTION" dapat meningkatkan keterampilan stimulasi literasi pada guru TK. Hal penting yang perlu diperhatikan dalam pelatihan "ACTION" adalah adanya interaksi sosial antara fasilitator, kofasilitator, dan peserta pelatihan, serta media yang dapat digunakan guru untuk praktik dalam kehidupan sehari-hari.

Saran

Diharapkan lebih antisipasi terhadap ancaman validitas internal, seperti proses seleksi subjek penelitian. Didalam modul pelatihan "ACTION" dapat ditambahkan sesi aktivitas praktik sebagai scaffolder aktivitas bermain sosiodrama pada setting sebenarnya untuk mengetahui implementasi pelatihan yang diberikan. Dapat menguji pengaruh pelatihan "ACTION" terhadap keterampilan stimulasi literasi pada subjek dengan ragam karakteristik yang berbeda dengan penelitian ini guna mendapatkan efektivitas pelatihan pada kelompok subjek yang lebih luas. Bagi subjek penelitian, disarankan untuk mempraktikkan teknik scaffolding menggunakan aktivitas bermain sosiodrama, agar subjek semakin terampil dalam memberikan stimulasi literasi

\section{Daftar Pustaka}

Banerjee, R,. Alsalman, A., \& Alqafari, S. (2016). Supporting sociodramatic play in preschools to promote language and literacy skills of english language learners. Early
Childhood Educational Journal, 44, 299-305. doi: 10.1007/s10643-0150715-4

Bodrova, E. \& Leong, D. J. (2007). Tools of the mind: The Vygotskian approach to early childhood. New Jersey: Pearson Education Inc.

Browne, A. (2001). Developing language and literacy 3-8 $2^{\text {nd }}$ edition. London: SAGE Publications.

Copple, C. \& Bredekamp, S. (2009). Developmentally appropriate practice in early childhood programs. United State of America: NAEYC Book.

Engin, M. (2014). Macro-scaffolding: Contextual support for teacher learning. Australian Journal of Teacher Education, 39, 26-40. doi: 10.14221/ajte.2014v39n5.6

Fani, T. \& Ghaemi, F. (2011). Implications of Vygotsky's Zone of Proximal Development (ZPD) in teacher education: ZPTD and selfscaffolding. Procedia Social and Behavioral Science, 29, 1549-1554. doi: 10.1016/j.sbspro.2011.11.396

Fritz, C. O., Morris, P. E., \& Richler, J. J. (2012). Effect size estimates: Current use, calculations, and interpretation. Journal of Experimental Psychology, 141, 12-18. doi: $10.1037 / \mathrm{a} 0024338$

Gmitrova, V. (2013). Teaching to play performing a main role-effective method of pretend play facilitation in preschool-age children. Early Child Development and Care, 11, 17051719. doi: $\underline{10.1080 / 03004430.2012 .746}$ $\underline{970}$

Goldstein, H. (2011). Knowing what to teach provides a roadmap for early literacy intervention. Journal of Early Intervention, 33(4), 268-280.

Howwit, D. \& Cramer, D. (2011). Introduction to statistic in psychology. Essex: Pearson Education Ltd. 
Justice, L. M, Mashburn, A., Pence, K. L., Wiggins, A. (2008). Experimental evaluation of a preschool language curriculum: Influence on children's expressive language skill. Journal of Speech, Language, and Hearing Research, 51, 938-100. doi: 10.1044/1092-4388(2008/072)

Morrow, L. M. (2007). Developing literacy in preschool. New York: The Guilford Press.

Pence, K. L., Justice, L. M., Wiggins, A. K. (2008). Preschool teachers fidelity in implementing a comprehensive language-rich curriculum. Language, Speech, and Hearing in School, 39, 329-341. doi: 10.1044/01611461(2008/031)

Roskos, K. A. \& Christie, J. F. (2013). Gaining ground in understanding the play-literacy relationship. American Journal of Play, 6(1), 82-97.

Roskos, K. \& Christie J. (2011). The playliteracy nexus and the importance of evidence-based technique in the classroom. American Journal of Play, 4(2), 204-224

Saracho, O. N. (2004). Supporting literacyrelated play: Roles for teachers of young children. Day Care and Early Education 31(3), 201-206

Schachter, R. E., Spear, C. F., Piata, S. B, Justice, L. M, \& Logan, J. A. R. (2016). Early childhood educators knowledge, beliefs, education, experiences, and children's language and literacy learning opportunities: What is the connection. Early Childhood Research Quarterly, 36, 281-294. doi: 10.1016/j.ecresq.2016.01.008

Shabani, K., Khatib, M., \& Ebadi, S. (2010). Vygotsky's zone of proximal development: Instructional implications and teacher's professional development. English Language Teaching, 3(4), 237-248.

Shadish, W. R, Cook, T. D., \& Campbell, D. T. (2002). Experimental and quasi-experimental design for generalized causal inference. New York: Houghton Mifflin Company.

Sugiyanto. (2009). Manipulasi: karakteristik eksperimen. Buletin Psikologi. 17(2), 98-108.

Trawick-Smit, J. \& Dziurgot, T. (2011). 'Good-fit' teacher-child play interventions and subsequent autonomous play of preschool children, Early Childhood Research Quarterly, 26, 110-123. doi: 10.1016/j.ecresq.2010.04.005

Turnbull, K. P., Anthony, A. B., Justice, L., Bowles, R. (2009). Preschoolers exposure to language stimulation in classrooms serving at-risk children: The contribution of group size and activity context. Early Education and Development, 20(1), 53-79. doi: 10.1080/ $\underline{10409280802206601}$

Van de Pol, J., Volman, M., \& Beishuizen, J. (2010). Scaffolding in teacherstudent interaction: Decade of research. Educational Psychology Review, 22(3), 271-296. doi: 10.1007/s10648-010-9127-6

Vygotsky, L. S. (1978). Mind in society the development of higher psychological processes. United States of America: President and Fellows of Harvard College.

Warford, M. K. (2011). The zone of proximal teacher development. Teaching and Teacher Education, 21, 252-258. doi: 10.1016/j.tate.2010.08. $\underline{008}$

Wasik, B. A. (2010). What teacher can do to promote preschoolers vocabulary development: stategies 
from an effective language and literacy professional development coaching model. The Reading Teacher, 63(8), 621-633. doi: 10.1598/RT.63.8.1
Whitehead, M. R. (2007). Developing language and literacy with young children $3^{\text {th }}$ ed. London: SAGE Publication Company. 